\title{
Postoperative pulmonary complications in noncardiothoracic surgery
}

\author{
Kardiyotorasik dışı cerrahilerde postoperatif pulmoner komplikasyonlar
}

\author{
Esra Büyük, Derya Hoşgün, Evrim Eylem Akpınar, Sümeyye Alparslan Bekir
}

Gönderilme tarihi:14.05.2020

Kabul tarihi:24.06.2020

\begin{abstract}
Purpose: Postoperative pulmonary complications (PPCs) are a major cause of mortality and morbidity. The aim of this study is to evaluate frequencies and determine risk factors of PPCs which developed subsequent to general surgery and orthopedic surgery in a tertiary university hospital.

Materials-methods: Patients who were operated in Departments of General Surgery and Orthopedics and Traumatology were retrospectively included to the study.

Results: 683 patients with a mean age of $59.43 \pm 18.77$ years were included in the study. The ratio of PPC was $10.3 \%$. Most frequent PPC was found to be pneumonia (6.3\%). The prevelance of PPC was significantly higher in patients $\geq 65$ years than who were $<65$ years old $(18.2 \%$ vs $4.4 \%)(p<0.001)$. PPC was more frequent in patients who undergone urgent surgery than those who undergone elective surgery $(24.1 \%$ vs $8 \%)(p<0.001)$. The rates of development of PPC according to the duration of operation (30 min-1 h, 1-2 h, 2-3 h, 3-4 h, >4 h) were respectively as follows $2.8 \%, 9.5 \%, 25 \%, 75 \%$ and $100 \%(p<0.001)$. Multivariable logistic regression analysis showed that being $\geq 65$ years, having $A S A \geq 3$ and hypoalbuminemia $(<3 \mathrm{~g} / \mathrm{dl})$ were independent risk factors for development of PPC (OR:2.45, 95\% Cl (1.14-5.25) $p<0.05$; OR: 44.5, 95\% Cl (5.13-386.1) $p<0.05$; OR:6.4, 95\% Cl (3.14-13.1) $p<0.05)$.

Conclusion: The clinicians should be aware of PPCs especially in patients who were $\geq 65$ years, had ASA $\geq 3$ and hypoalbuminemia $(<3 \mathrm{~g} / \mathrm{dl})$.
\end{abstract}

Key words: PPCs, surgery, mortality.

Buyuk E, Hosgun D, Akpinar EE, Alparslan Bekir S. Postoperative pulmonary complications in noncardiothoracic surgery. Pam Med J 2021;14:31-41.

\section{Özet}

Amaç: Postoperatif pulmoner komplikasyonlar (PPK) önemli mortalite ve morbidite sebebidir. Çalışmamızın amacı ortopedi ve genel cerrahi operasyonlarından sonra gelişen PPK sıklığını ve risk faktörlerini belirlemektir. Gereç ve yöntem: Genel cerrahi, ortopedi ve travmatoloji kliniklerinde opere edilen hastalar retrospektif olarak değerlendirildi.

Bulgular: Ortalama yaşı 59,43ะ18,77 yıl olan 683 hasta çalışmaya alındı.PPK \%10,3 idi. Pnömöni (\%6,3) en sık görülen PPK olarak tespit edildi. PPK sıklığı 65 yaş ve üstünde altında göre belirgin olarak yüksek saptandı. $(\% 18,2$ vs $\% 4,4)(p<0,001)$. Acil cerrahi operasyonlarda elektif operasyonlara göre daha sık tespit edildi $(\% 24,1$ vs \%8) $(p<0,001)$. Operasyon süresinine göre (30 dk-1 st, 1-2 st, 2-3 st, 4 st, $>4$ st) PPK gelişim oranı sırasıyla $\% 2,8, \% 9,5, \% 25, \% 75$ ve \%100 olarak bulundu $(p<0,001)$. Çok değişkenli logiistik regresyon analizine göre $A S A \geq 3$, hipoalbunemi $(<3 \mathrm{~g} / \mathrm{dl})$ ve 65 yaş üstü PPK gelişiminde bağımsız risk faktörü olarak saptandı $(O R: 2,45$, \%95 Cl $(1,14-5,25) p<0,05$; OR: 44,5, \%95 Cl $(5,13-386,1) p<0,05$; OR: 6,4, \%95 Cl $(3,14-13,1) p<0,05)$.

Sonuç: Klinisyenler preoperative değerlendirmede $A S A \geq 3$, hipoalbunemi $(<3 \mathrm{~g} / \mathrm{dl})$ ve 65 yaş üzerindeki hastalarda PPK açısından dikkatli olmalıdır.

Anahtar kelimeler: PPPK, cerrahi, mortalite.

Büyük E, Hoşgün D, Akpınar EE, Alparslan Bekir S. Kardiyotorasik dışı cerrahilerde postoperatif pulmoner komplikasyonlar. Pam Tıp Derg 2021;14:31-41.

Esra Büyük, Specialist, Department of Pulmonary Medicine, Çankırı State Hospital, Çankırı, Turkey, e-mail: esra16.dr@gmail.com (orcid. org/0000-0001-8568-7523) (Corresponding Author)

Derya Hoşün, Specialist, Specialist in Intensive Care, Department of Intensive Care Unit, Atatürk Chest Disease and Surgery Training and Research Hospital, Ankara, Turkey, e-mail: deryahosgun@gmail.com (orcid.org/0000-0003-1221-3620)

Evrim Eylem Akpınar, Prof. Department of Pulmonary Medicine, Ufuk University School of Medicine, Ankara, Turkey e-mail: drevrimeylem@ gmail.com (orcid.org/0000-0001-9040-9309)

Sümeyye Alparslan Bekir, Specialist, Department of Pulmonology, Süreyyapaşa Chest Disease and Thoracic Surgery Training and Research Hospital, İstanbul, Turkey, e-mail: sabekir@gmail.com (orcid.org/0000-0002-3542-8133) 


\section{Introduction}

Every surgical intervention has some postoperative risks. Postoperative pulmonary complications (PPC) are among commonly seen causes of morbidity, mortality and increase length of hospital stay and cost following surgical procedures. The frequencies of PPCs subsequent to non-cardiothoracic surgery were found as common as cardiac ones $[1,2]$. The reported mortality rate was $5 \%$ for patients who were undergoing general surgery operation and it may increase up to $20 \%$ in high risk procedures. Atelectasis, pneumonia, pulmoner tromboembolism, acute respiratory distress syndrome (ARDS), pleural effusion and exacerbation of underlying lung disease e.g. Chronic obstructive pulmonary disease (COPD), asthma are some of the postoperative clinical conditions related to lungs [1].

Identification of risk factors for PPCs are important to make an effective preoperative evaluation and try to prevent development and for appropriate management of them. Frequencies and risk factors of PPCs were variable in literature and many factors related to characteristics of patients, surgery and anesthesia may interact and contribute to the development of PPCs [3].

Aim of the study to evaluate frequencies and determine risk factors of PPCs which developed subsequent to general surgery and orthopedic surgery in a tertiary university hospital.

\section{Material and methods}

Patients who were operated in Departments of General Surgery $(n=315)$ and Orthopedics and Traumatology $(n=368)$ between the dates of June 2012 and June 2013 were retrospectively included to the study. Patients who were older than 18 years and whose medical records were accessible were included to the study. The exclusion criteria were being $\leq 18$ years old and failure in acquiring the medical records. Fourty five of patients in General
Surgery group and 38 patients in Orthopedics and Traumatology group who were not met inclusion criteria were excluded and finally 600 patients (270 of General Surgery patients and 330 of Orthopedics and Traumatology patients) were included to the study. Medical records from the electronic database of hospital were used to obtain information about the patients. Characteristics of the patients and properties of operations, postoperative care methods, type of postoperative pulmonary complications, lenght of hospitalization and mortality rate were recorded. Table1 shows recorded parameters of the patients. Development of PPCs determined $\mathrm{vi}$ investigation of progresses that were recorded by surgeons and consultation notes that were requested from Department of Chest Diseases. The study protocol was approved by the local ethical committee (Ufuk University Non-Interventional Clinical Research approved by the Ethics Committee).

Statistical analyses were performed using SPSS 15.0 (Statistical Package for Social Sciences for Windows). The descriptive statistics were expressed as mean \pm standard deviation for variables having normal distrubution and median (minimum-maximum) for variables which were not normally distrubuted, and nominalvariables were demonstrated as frequencies (percentages). The significance of difference in terms of means were evaluated by Student's t test, and for that of medians Mann Whitney $U$ test was used.

Nominal variables were evaluated by Pearson Chi-square or Fisher's exact test and $p$ values $<0.05$ were considered as statistically significant. The variables which were found significant in univariable analysis were used for multivariable logistic regression analysis with Backward elimination that was performed to define independent risk factors for development of pulmonary complication and risk coefficiens were given. 
Table 1. Characteristics of the patients and properties of operations, postoperative care methods, type of postoperative pulmonary complications that were accessed from medical records on electronic database of the hospital

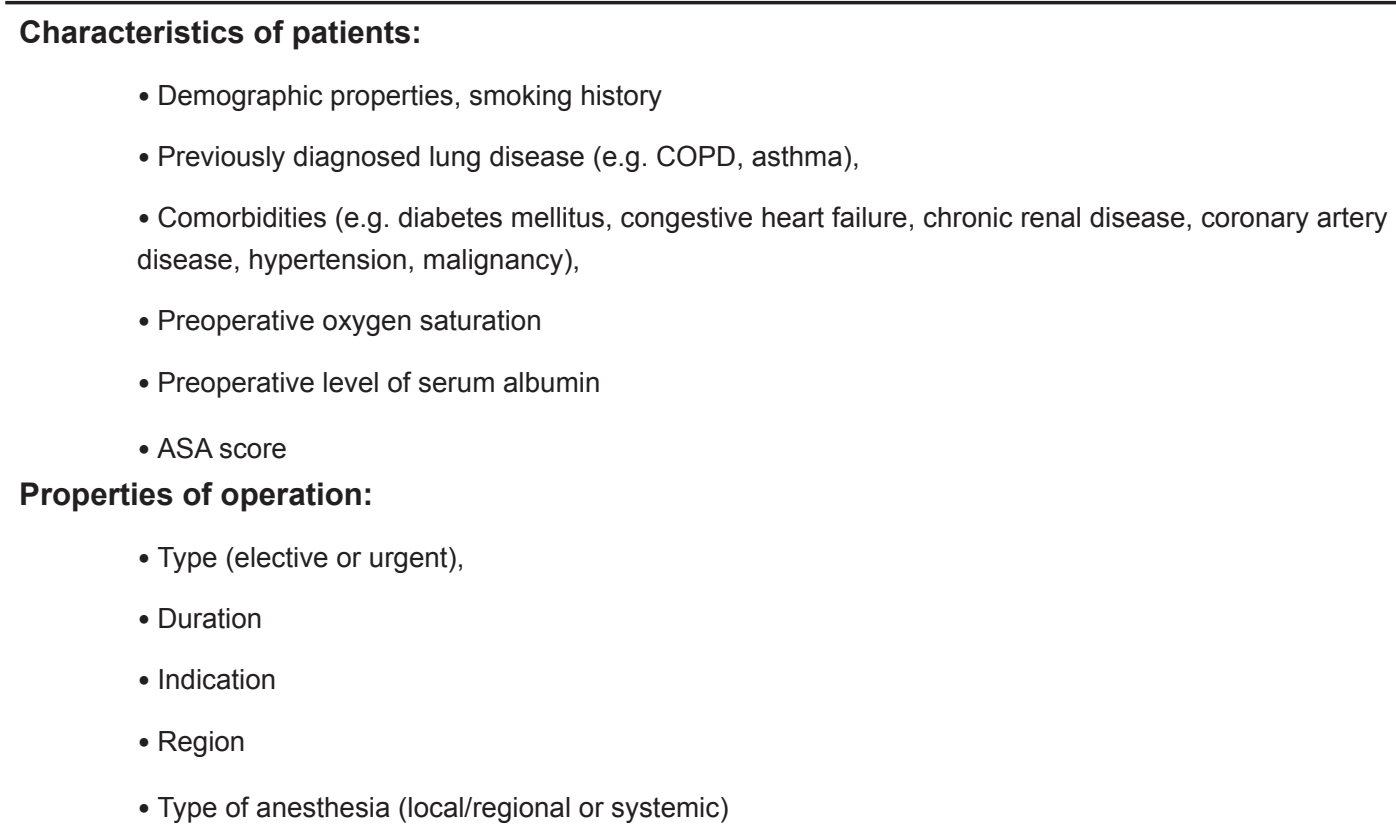

Postoperative care method: pain relief, postural drainage, use of mucolytic, use of intensive spirometry, use of venous thrombophlaxis, mobilization time following surgery

Type of postoperative pulmonary complication: Pneumonia, pulmonary thromboembolism, ARDS, pleural effusion, COPD/asthma exacerbation

Length of hospitalization

Mortality

COPD: Chronic obstructive pulmonary disease, ASA: American Society of Anesthesiologists ARDS: Acute respiratory distress syndrome

\section{Results}

Three hundred and seventy of patients $(61.7 \%)$ were female and rest of them were male $(n=230,38.3 \%)$. Mean age of patients was $59.43 \pm 18.77$ years. Demographic properties, clinical characteristics, type of anesthesia and operation on admission to the hospital were demonstrated on table 2 .

Fifty two of the patients $(8.7 \%)$ had accompanying lung disease (asthma $n=15$, COPD $n=33$ ). Most prevelant comorbidity was hypertension (45.4\%). The percentages of other comorbidities were as follows: Diabetes mellitus $7 \%$, coronary artery disease $4.8 \%$, congestive heart failure $1.9 \%$, chronic renal disease $0.3 \%$.
Laparoscopic gall bladder operation was the most common one (32\%) among general surgical procedures, knee operation was the most frequent one (68\%) among orthopedics surgery. The regions of operation according to type of operation were shown on table 3 .

The ratio of PPC was $10.3 \%(n=62)$. Most frequent PPC was found to be pneumonia (6.3\%, $\mathrm{n}=38$ ). Pulmonary tromboembolism (PE) had developed in 12 patients $(2.0 \%)$. The frequencies of pleural effusion and atelectasis were $1 \%(n=6)$ and $0.5 \%(n=3)$, respectively. The prevelance of PPC was significantly higher in patients $\geq 65$ years than who were $<65$ years old $(18.2 \%$ vs $4.4 \%)(p<0.001)$. The ratio of PPC according to body mass index was highest among underweight patients $(33.3 \%)(p<0.031)$. 
Table 2. Demographic properties, clinical characteristics, type of anesthesia and operation on admission to the hospital

\begin{tabular}{|c|c|c|c|}
\hline & & $\mathbf{n}$ & $\%$ \\
\hline Gender & $\begin{array}{l}\text { Female } \\
\text { Male }\end{array}$ & $\begin{array}{l}370 \\
230\end{array}$ & $\begin{array}{l}61.7 \\
38.3\end{array}$ \\
\hline Age (years) & $\begin{array}{l}<65 \\
\geq 65\end{array}$ & $\begin{array}{l}342 \\
258\end{array}$ & $\begin{array}{l}57 \\
43\end{array}$ \\
\hline $\begin{array}{l}\text { Body Mass Index } \\
\text { Underweight } \\
\text { Normal weight } \\
\text { Overweight } \\
\text { Obese }\end{array}$ & $\begin{array}{l}\leq 18.5 \\
18.5-24.9 \\
25-29.9 \\
\geq 30\end{array}$ & $\begin{array}{l}12 \\
273 \\
254 \\
61\end{array}$ & $\begin{array}{l}2 \\
45.5 \\
42.3 \\
10.2\end{array}$ \\
\hline Smoking history & $\begin{array}{l}\text { Current smoker } \\
\text { Ex smoker } \\
\text { Never smoker }\end{array}$ & $\begin{array}{l}137 \\
171 \\
292\end{array}$ & $\begin{array}{l}22.8 \\
28.5 \\
48.7\end{array}$ \\
\hline ASA & $\begin{array}{l}\text { I } \\
\text { II } \\
\text { III } \\
\text { IV }\end{array}$ & $\begin{array}{l}83 \\
465 \\
51 \\
1\end{array}$ & $\begin{array}{l}13.8 \\
77.5 \\
8.5 \\
0.2\end{array}$ \\
\hline Preoperative SPO2 (\%) & $\begin{array}{l}100-95 \\
94-90 \\
\geq 89\end{array}$ & $\begin{array}{l}501 \\
85 \\
13\end{array}$ & $\begin{array}{l}83.5 \\
14.2 \\
2.2\end{array}$ \\
\hline Albumin (g/dl) & $\begin{array}{l}\text { Normal } \geq 3 \\
\text { Düşük }<3\end{array}$ & $\begin{array}{l}511 \\
89\end{array}$ & $\begin{array}{l}85.2 \\
14.8\end{array}$ \\
\hline Type of anesthesia & $\begin{array}{l}\text { General } \\
\text { Regional }\end{array}$ & $\begin{array}{l}265 \\
335\end{array}$ & $\begin{array}{l}44.2 \\
55.8\end{array}$ \\
\hline Type of operation & $\begin{array}{l}\text { General surgery } \\
\text { Elective } \\
\text { Urgent } \\
\text { Orthopedics } \\
\text { Elective } \\
\text { Urgent } \\
\text { TOTAL }\end{array}$ & $\begin{array}{l}270 \\
237 \\
33 \\
330 \\
276 \\
54 \\
600\end{array}$ & $\begin{array}{l}\mathbf{4 5} \\
87.8 \\
12.2 \\
\mathbf{5 5} \\
83.6 \\
16.4 \\
\mathbf{1 0 0}\end{array}$ \\
\hline
\end{tabular}

ASA: American Society of Anesthesiologists, SPO2: oxygen saturation

Table 3. The regions of operation according to type of operation

\begin{tabular}{lll}
\hline & $\mathbf{n}$ & $\%$ \\
\hline General surgery operations & & \\
Neck & 19 & 7.2 \\
Breast & 19 & 7.2 \\
Upper abdomen & 21 & 7.7 \\
Lower abdomen & 73 & 27.1 \\
Laparoscopic bladder & 87 & 32 \\
Gluteal region & 51 & 18.8 \\
Total & $\mathbf{2 7 0}$ & $\mathbf{1 0 0}$ \\
Orthopedics operations & & \\
Upper extremity & & \\
Lower extremity-Knee & 25 & 7.0 \\
Lower extremity-Femur & 223 & 68.0 \\
Total & 82 & 25.0 \\
\hline
\end{tabular}


The effect of ASA score, anesthesia type, type and region of operation on development of PPC were evaluated. There was positive correlation between ASA score and development of PPC. Forty of the patients who developed PPC $(64.5 \%)$ had taken general anesthesia, 22 of them $(35.5 \%)$ had taken regional anesthesia $(p<0.001)$.

PPC was more frequent in patients who undergone urgent surgery than those who undergone elective surgery $(24.1 \%$ vs $8 \%)$ $(p<0.001)$. PPC development was most frequent among patients who were operated from upper abdomen when compared with other sites of general surgery $(p<0.005)$. PPC was significantly more frequent subsequent to femur operations than other orthopedics surgeries $(p<0.001)$. Table 4 shows frequencies of PPCs according to ASA score, type of anesthesia, type and region of operation.

The evaluation of the effects of the postoperative interventions showed that PPC was less frequent in patients who were applied postural drainage and used mucolytics than in who were not given these treatments $(p<0.001$ for both). The incedence of PPC was higher in intensive spirometry used group than in who did not use it $(p<0.001$ for all). The patients who mobilized later than 24 hours developed more PPC than who mobilized earlier $(p<0.001)$. Table 5 shows the relationship between postoperative intervention and development of PPC.

The ratio of the patients who had at least 1 comorbidity was $46 \%$. The rate of development of PPC was significantly higher among patients who had at least 1 comorbidity than who did not have any comorbidity $(17.6 \%$ vs $1.8 \%)$ $(p<0.001)$.

The rate of the observed PPC in patients who had hypoalbuminemia $(<3 \mathrm{~g} / \mathrm{dl})$ was higher than who had normal level of serum albumin ( $\geq 3 \mathrm{~g} / \mathrm{dl})$ $(40.4 \%$ vs $5.1 \%)(p<0.005)$. The patients whose duration of operation was $<30 \mathrm{~min}(n=27)$ did not developed any PPC. Five of 183 patients $(2.8 \%)$ who had operation time between $30 \mathrm{~min}$ and $1 \mathrm{~h}$ developed PPC

The rates of development of PPC according to the duration of operation (30 min-1 h, 1-2 h, 2-3 h, 3-4 h, >4 h) were respectively as follows $2.8 \%, 9.5 \%, 25 \%, 75 \%$ and $100 \%(p<0.001)$. Figure 1 shows the relationship between duration of operation and development of PPC.

Table 4. The relationship between PPCs and ASA score, type of anesthesia, type and region of operation

\begin{tabular}{|c|c|c|c|c|}
\hline & & \multicolumn{2}{|l|}{ PPC } & \multirow[t]{2}{*}{$p$} \\
\hline & & Present n (\%) & Absent n (\%) & \\
\hline ASA score & $\begin{array}{l}\text { I } \\
\text { II } \\
\text { III } \\
\text { IV }\end{array}$ & $\begin{array}{l}1(1.2) \\
25(5.4) \\
35(68.6) \\
1(100)\end{array}$ & $\begin{array}{l}82(98.8) \\
440(94.6) \\
16(31.4) \\
0(0)\end{array}$ & $<0.001$ \\
\hline Type of anesthesia & $\begin{array}{l}\text { General } \\
\text { Regional }\end{array}$ & $\begin{array}{l}40(15.1) \\
22(6.6)\end{array}$ & $\begin{array}{l}225(84.9) \\
313(93.4)\end{array}$ & 0.001 \\
\hline Type of operation & $\begin{array}{l}\text { Urgent } \\
\text { Elective }\end{array}$ & $\begin{array}{l}21(24.1) \\
41(8)\end{array}$ & $\begin{array}{l}66(75.9) \\
472(92)\end{array}$ & $<0.001$ \\
\hline $\begin{array}{l}\text { Region of general } \\
\text { surgery }\end{array}$ & $\begin{array}{l}\text { Neck } \\
\text { Breast } \\
\text { Upper abdomen } \\
\text { Lower abdomen } \\
\text { Laparoscopic } \\
\text { bladder } \\
\text { Gluteal region }\end{array}$ & $\begin{array}{l}1(5.3) \\
4(19) \\
6(28.6) \\
19(26) \\
3(3.4) \\
0(0)\end{array}$ & $\begin{array}{l}18(94.7) \\
17(81) \\
15(71.4) \\
54(74) \\
84(96.6) \\
51(100)\end{array}$ & $<0.001$ \\
\hline $\begin{array}{l}\text { Region of orthopedics } \\
\text { surgery }\end{array}$ & $\begin{array}{l}\text { Upper extremity } \\
\text { Lower extremity- } \\
\text { Knee } \\
\text { Lower extremity- } \\
\text { Femur }\end{array}$ & $\begin{array}{l}0(0) \\
12(5.4) \\
17(20.7)\end{array}$ & $\begin{array}{l}23(100) \\
211(94.6) \\
65(79.3)\end{array}$ & $<0.001$ \\
\hline
\end{tabular}

PPC: Postoperative pulmonary complication, ASA: American Society of Anesthesiologists 
Table 5. The relationship between postoperative intervention and development of PPC

\begin{tabular}{|c|c|c|c|c|}
\hline \multirow[b]{2}{*}{$\begin{array}{l}\text { Postoperative } \\
\text { Intervention }\end{array}$} & & \multicolumn{2}{|l|}{ PPC } & \multirow[t]{2}{*}{$p$} \\
\hline & & Present & Absent & \\
\hline $\begin{array}{l}\text { Postural drainage } \\
\text { n (\%) }\end{array}$ & $\begin{array}{l}\text { Present } \\
\text { Absent }\end{array}$ & $\begin{array}{l}45(72.6) \\
17(27.4)\end{array}$ & $\begin{array}{l}154(28.6) \\
384(71.4)\end{array}$ & $<0.001$ \\
\hline $\begin{array}{l}\text { Mucolytic use } \\
\text { n (\%) }\end{array}$ & $\begin{array}{l}\text { Present } \\
\text { Absent }\end{array}$ & $\begin{array}{l}35(57.4) \\
26(42.6)\end{array}$ & $\begin{array}{l}83(15.4) \\
455(84.6)\end{array}$ & $<0.001$ \\
\hline $\begin{array}{l}\text { Intensive } \\
\text { spirometry use } \\
\text { n (\%) }\end{array}$ & $\begin{array}{l}\text { Present } \\
\text { Absent }\end{array}$ & $\begin{array}{l}38(61.3) \\
24(38.7)\end{array}$ & $\begin{array}{l}120(22.3) \\
418(77.7)\end{array}$ & $<0.001$ \\
\hline LMWH & $\begin{array}{l}\text { Present } \\
\text { Absent }\end{array}$ & $\begin{array}{l}11(2.3) \\
1(0.9)\end{array}$ & $\begin{array}{l}472(97.7) \\
116(99.1)\end{array}$ & $>0.05$ \\
\hline $\begin{array}{l}\text { Duration of } \\
\text { mobilization (hour) }\end{array}$ & $\begin{array}{l}0-6 \\
6-12 \\
12-24 \\
>24\end{array}$ & $\begin{array}{l}7(6) \\
11(6.1) \\
25(11.4) \\
15(19.7)\end{array}$ & $\begin{array}{l}110(94) \\
170(93.9) \\
195(88.6) \\
61(80.3)\end{array}$ & $<0.001$ \\
\hline
\end{tabular}

LMWH: Low molecular weight heparin, PPC: Postoperative pulmonary complication

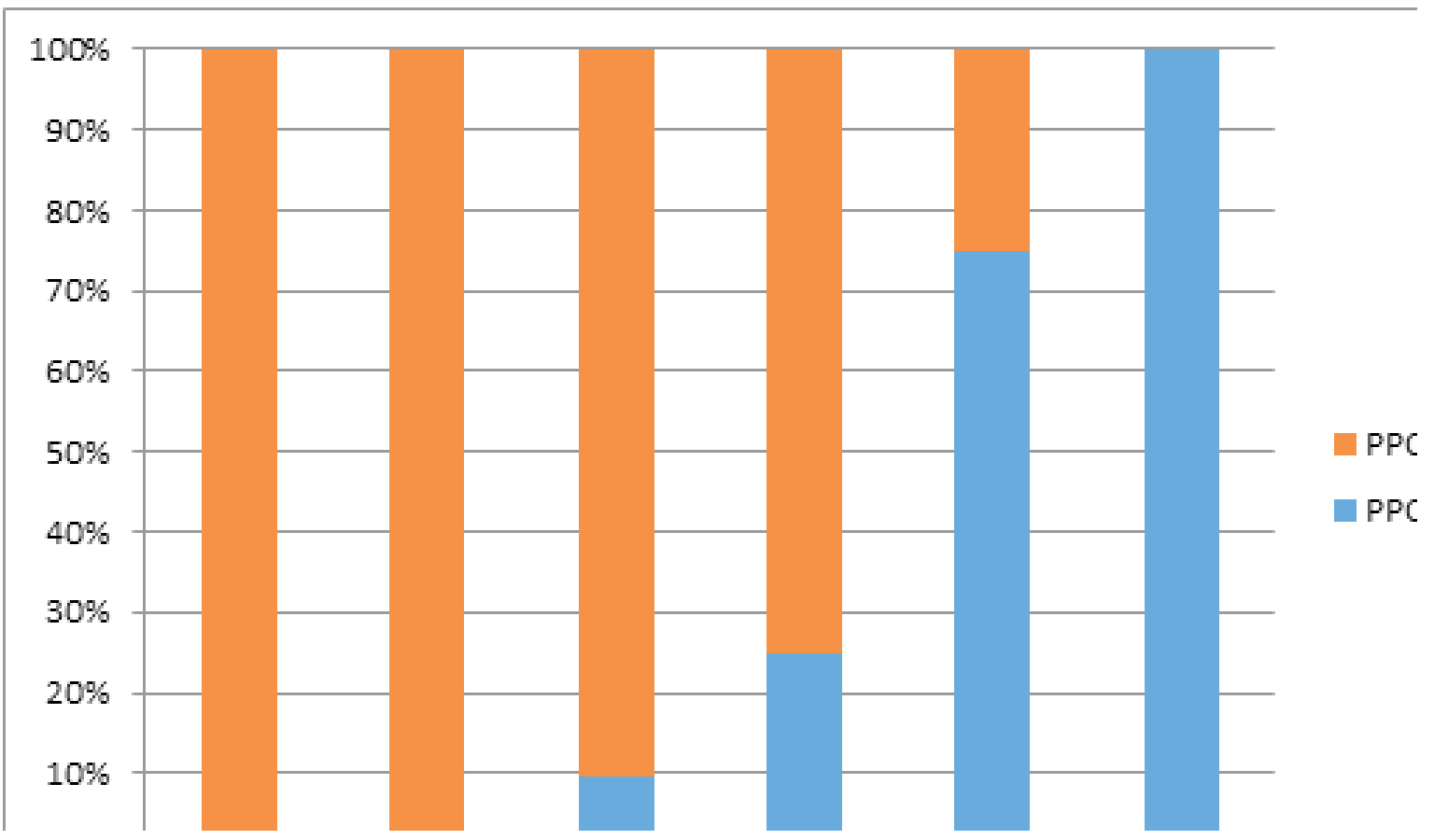

Figure 1. The relationship between duration of operation and development of PPC

The median values of length of hospitalization in patients who developed PPC and who did not were respectively as follows (9.5 day (min:1-max:90 day), 3 day (min:1-max:23) day) $(p<0.001)$. Mortality rate was significantly higher among patients who developed PPC than who did not $(10.3$ vs $0.2 \%)(p<0.001)$.

Multivariable logistic regression analysis showed that being $\geq 65$ years, having $A S A \geq 3$ and hypoalbuminemia $(<3 \mathrm{~g} / \mathrm{dl})$ were independent risk factors for development of PPC (OR:2.45,
95\% Cl (1.14-5.25) $p<0.05$; OR: 44.5, 95\% Cl (5.13-386.1) $p<0.05$; OR:6.4, $95 \% \mathrm{Cl}(3.14-$ 13.1) $p<0.05)$.

\section{Discussion}

Main results of this study were as follows: Most frequent PPC was found to be pneumonia. The prevelance of PPCs was higher in patients who were underweight, undergone urgent surgery and who were given generel anesthesia. While duration of operation was lengthening, rate of PPC was increased. Upper 
abdomen was the operation site which was most prone to development of PPC among generel surgery patients and femur was the one in patients who undergone orthopedics surgery. Postoperative interventions such as application of postural drainage and use o mucolytics may decrease the risk of development of PPC. Lenght of hospital stay and mortality rate was higher in PPC developed patients than who did not. Being $\geq 65$ years, having $A S A \geq 3$ and hypoalbuminemia $(<3 \mathrm{~g} / \mathrm{dl})$ were independent risk factors for development of PPC.

Postoperative pneumonia which is the most frequent PPC in thoracic surgery, also is frequently seen subsequent non-cardiothoracic surgery [4-8]. The rate of postoperative pneumonia following non thoracic surgery was variable in different studies (1.5\%-14.7\%) and $6.3 \%$ in our study. This variation between studies may be as a result of heterogenity of the study populations and type of operation. Pneumonia development rate was high in studies including patients who undergone upper abdomen operation [7]. The ratio of upper abdominal operations was $7.7 \%$ in our study population, relatively lower than other studies $[7,8]$. The variablity in definition of pneumonia also might have been affective on postoperative pneumonia rate. The rate was higher in studies that used only clinical and radiolological findings rather than isolation of pathogen [8, 9]. We also diagnosed pneumonia according to clinical and radiological findings.

Pulmonary embolism (PE) is a rare but potentially fatal complication of surgery. The rate of PE in our study was $2 \%$, relatively lower than other studies [10, 11]. Matsuoka et al. [10] investigated the risk factors for postoperative PE. They found the incedence of PE as $15 \%$. Two reason might be effective on lower incedence of PE in our study; First: In our study contrast enhanced multidedector computed tomography (MDCT) was performed only to the patients who had moderate-high clinical propabilty for PE. Whereas it was performed to both symptomatic and asymptomatic patients in the cited study [11]. Secondly, LMWH prophylaxis was given to almost all of the patients $(97.7 \%)$ in our study.

Although atelectasis was a relatively frequent complication in previous studies, it was the least frequent PPC in our study $(0.5 \%)$ $[5,7]$. In the study of Özdilekcan et al. [5] in which they investigated PPC after oncological surgery, atelectasis was the most frequent PPC $(13.7 \%)$. The real incidene of atelectasis may not be known exactly due to misclassification of atelectasis as pneumonia or secretion retention [11]. The retrospective method of the present study might have prevented to detect asymptomatic atelectasis. More than half of the cases (\%55) were operated with regional anesthesia, this also may be another reason of low rate of atelectasis in our study.

The older study results were controversial about whether the age was a risk factor for PPC or not. Smetana et al. [12] suggested that age did not solely cause PPC and the increase in the frequency of comorbidities with aging was the factor effective on development of PPC. Advancing age, even when adjusted for comorbidity, is predictive of PPCs. Recent studies have shown that age>60 or $65 \mathrm{yr}$ to be a risk factor [13, 14]. Aging causes decrease in lung volumes and compliance and predisposes to PPCs. In the present study consistently with the current literature, being $\geq 65$ years was found to be an independent risk factor for development of PPCs.

Besides studies emphasizing that obesity have increased the risk of PPCs some studies suggested that there was close relationship between malnutrition and PPCs by causing decrease in inspiration capacity, vital capacity, functional residual capacity and oxygenation [14-16]. Supporting these data, the present study showed that underweight patients had highest rate of PPC compared to the patients who were normal weight, overweight and obese.

Despite smoking is a well known risk factor for PPCs, our study did not find any significant difference between ex smoker, current smoker and never smoker patients Almost half of the patients $(48.7 \%)$ were never smokers in the present study [17]. This unequal distrubution of patients between the groups according to smoking history might have caused this result. Cessation for $>4$ weeks reduces PPCs by $23 \%$, and for $>8$ weeks by $47 \%$. Timing of smoking cessation also was not certain in the present study, because of its retrospective method.

Although ASA clinical classification had been developed to evaluate perioperative mortality, it is also a good indicator for PPCs [18]. Hall et al. 
[19] reported that PPCs were significantly higher in patients having ASA score $\geq 2$. Smetana et al. [12] also emphasized that ASA clinical scoring was closely related with PPCs. Our study also supported these results because we showed that having $A S A \geq 3$ was an independent risk factor for PPCs.

Hollman et al. [20] reported that use of epidural anesthesia prevents immediate postoperative hypercoagulability in patients undergoing major orthopedic surgery. Canet et al. [11] found higher incidence of developing at least one PPC in patients operated with general anesthesia compared with regional anesthesia in their prospective multicentre study of 2464 patients. Despite variability in type of surgery, the present study demonstrated that PPCs were more common among patients who were applied general anesthesia. This result is consistent with previous studies.

In a systematic review about preoperative pulmonary risk stratification for noncardiothoracic surgery, Smetana et al. [12] reported that patients undergoing emergency surgery had 2.21 fold higher risk for the development of PPCs. Supporting this result, we found a significantly higher incidence of PPC in patients with emergency surgery than in patients with elective surgery.

The site of the surgery also is one of the factors effective on development of PPCs. It is well known that surgery site closer to diaphragma higher the risk of development of PPCs. Patients are at high risk of developing PPCs after certain types of surgery. Pneumonia is significantly higher after abdominal aortic aneurysm repair, thoracic, upper abdominal, or neck surgery, neurosurgery, and major vascular surgery [14]. Pedersen et al. [21] investigated the incidence of PPC following upper and lower abdominal surgery and they found the incedence as 33\% and $16 \%$, respectively. The incedence of PPC after upper abdominal surgery was reported as $35 \%$ in Kocabaş et al.'s study [22]. In our study, the incidence of PPC following upper obdominal surgery was similar to literature $28.6 \%$ and the incedence of PPC after lower abdominal surgery was higher than in previous studies (26\%). The causative factor for this result may be the high ratio $(68 \%)$ of oncological surgery among lower abdominal operations.
Among orthophedics surgery femur surgery was the most frequent PPC (20.7\%) developing site of surgery in the present study. This ratio was relatively higher than literature, the reasons of this condition may be the high rates of urgent surgery, older patients, late mobilization and high number of associated comorbidity in the femur surgery subgroup of the patients [14].

Postoperative pain control, postural drainage, use of mucolytics, PE prophylaxis, intensive spirometry and early mobilization are the interventions that may decrease the risk of PPCs.

Effective analgesia has an important role on prevention of postoperative pneumonia [14]. In the present study PPC incedence was not significantly diffrent in groups of patients who were applied postoperative analgesia $(n=586)$ or not $(n=14)$. The disproportionate distrubution of patients among groups may be the cause of this unexpected result. We found lower incidence of PPC among patients who were applied postural drainage, mobilized early, used mucolytics than patients who were not, as compatible with previous studies [14]. Surprisingly, intensive spirometry use seems to be not preventive against PPC. In the present study, the use of intensive spirometry was not followed up after recommendation of it, so that we were not sure how much of the patients appropriately have used intensive spirometry. The present study showed that patients who had at least one comorbidity developed more frequent PPC, this is an expected result according to a guideline for prevention of perioperative pulmonary complication in patients undergoing non-cardithoracic surgery and a recent review of PPCs, both stated that presence and number of comorbidities increases risk of PPCs [14, 18]. This result is important because, comorbidities are modifiable to a certain extent in that preoperative medical optimizationis possible.

Serum albumin level is the most extensively studied biomarker in diagnosis of malnutrition. Previous studies reported that serum albumin was a useful indicator of overall nutrition status especially in older adults who do not have any acute illness [23]. Although hypoalbuminemia was defined as a risk factor for morbidity and mortality following cardiac and elective oncological rectal surgery, the relationship between preoperative hypoalbuminemia and 
PPCs was not extensively investigated [24, 25]. Li et al. [26] demonstrated that $\geq 14.97 \%$ decrease in albumin levels, increased risk of developing PPCs after lung cancer surgery. Ryan et al. [27] reported that serum albumin concentration $<2 \mathrm{gr} / \mathrm{dl}$ on the first postoperative day was a good predictor for respiratory failure and ARDS. The threshold for hypoalbuminemia showed heterogenity among the different studies (2.5-3.5 gr/dl) [27]. Consistently with these results, we observed that hypoalbuminemia was a strong predictor for PPCs (OR:6.4, 95\% Cl (3.14-13.1)). The treshold for hypoalbuminemia was $<3 \mathrm{~g} / \mathrm{dl}$ in the present study.

Although the relationship of hypoalbuminemia and worse outcome following operations has been known for a long time, the pathophysiology behind the relationship is yet not clear. Three suggestions might explain this relationship. First, because albumin might serve as a nutritional marker, hypoalbuminemia represents poor nutritional status in patients who undergo surgery. Second, albumin also acts as an antioxidant or transporter, and therefore, the deficiency might result in poor surgical outcomes. Third, albumin is a negative acute phase reactant so that hypoalbuminemia might represent a high level of inflammation that may lead to poor outcomes after surgery [28].

In their review about PPCs, Miskovic et al. [14] reported that a duration of surgery and anaesthesia of $>2 \mathrm{~h}$ is independently associated with PPC development Supporting this data, we observed that the longer duration of operation, the higher PPC rate. The experience of the surgeon may be effective on the duration of operation.

The study had some limitations; First, the method was retrospective and the evaluation of PPCs based on chest diseases counsultation of related surgeons. So that, asymptomatic PPCs and the ones which could not be noticed by surgeons might be underestimated. Secondly because the frequency of pulmoner comorbidity was very low in the study population statistical analysis could not be made to evaluate the effect of them on PPC development.

As a result of the present study showed that morbidity and mortality was significantly higher among patients who developed PPCs in non- cardiothoracic surgery. The clinicians should be aware of PPCs especially in patients who were $\geq 65$ years, had $A S A \geq 3$ and hypoalbuminemia $(<3 \mathrm{~g} / \mathrm{dl})$. It should be kept in mind that being underweight also may predispose to development of PPCs. The use of regional anesthesia rather than general anesthesia, shortening of duration as much as possible, use of mucolytics and postural drainage following surgery, early mobilization, preference of laparoscopic method and management of comorbidities preoperatively may decrease the incidence of PPCs. Carefull preoperative evaluation is important to determine risk of PPCs. Further prospective larger studies are needed to clarify preventive measures for PPCs.

Conflicts of interest: The authors declare no potential conflicts of interest.

\section{References}

1. Canet J, Mazo V. Postoperative pulmonary complications. Minerva Anestesiol 2010;76:138-143.

2. Davies OJ, Husain T, Stephens RCM. Postoperative pulmonary complications following non-cardiothoracic surgery. BJA Education 2017;17:295-300. https://doi. org/10.1093/bjaed/mkx012

3. Taylor A, DeBoard Z, Gauvin JM. Prevention of postoperative pulmonary complications. Surg Clin North Am 2015;95:237-254. https://doi.org/10.1016/j. suc.2014.11.002

4. ASA Physical Status Classification System, developed by: ASA house of delegates/executive committee last amended. Available at: https://www.asahq. org/standards-and-guidelines/asa-physical-statusclassification-system. Accessed October 15, 2014

5. Özdilekcan Ç, Songur N, Berktaş BM, Dinç M, Üçgül E, OK U. Risk factors associated with postoperative pulmonary complications following oncological surgery. Tüberküloz ve Toraks Dergisi 2004;52:248-255.

6. Kozower BD, Sheng S, O'Brien SM, et al. STS database risk models: predictors of mortality and major morbidity for lung cancer resection. Ann Thorac Surg 2010;90:875-881. https//doi.org/10.1016/j. athoracsur.2010.03.115

7. Saracoglu A, Yavru A, Kucukgoncu S, et al. Predictive factors involved in development of postoperative pulmonary complications. Turk J Anaesth Reanim 2014;42:313-319. https//doi.org/10.5152/ TJAR.2014.50133

8. Annakkaya AN, Tozkoparan E, Deniz O, et al. Postoperatif solunumsal komplikasyonlar. Toraks Dergisi 2005:6:104-108. 
9. Arozullah AM, Khuri SF, Henderson WG, Daley $J$. Development and validation of a multifactorial risk index for predicting postoperative pneumonia after major noncardiac surgery. Ann Intern Med 2001;135:847-857. https//doi.org/10.7326/0003-4819135-10-200111200-00005

10. Matsuoka $\mathrm{Y}$, Morimatsu $\mathrm{H}$. Incidence rates of postoperative pulmonary embolisms in symptomatic and asymptomatic patients, detected by diagnostic images, a single-center retrospective study. Circ J 2019;83:432-440. https//doi.org/10.1253/circj.CJ-180729

11. Canet J, Gallart L, Gomar C, et al. Prediction of postoperative pulmonary complications in a populationbased surgical cohort. Anesthesiology 2010;113:13381350. https://doi.org/10.1097/ALN.0b013e3181fc6e0

12. Smetana GW, Lawrence VA, Cornell JE. Preoperative pulmonary risk stratification for noncardiothoracic surgery: systematic review for the American College of Physicians. Ann Intern Med 2006;144:581-595. https:// doi.org/10.7326/0003-4819-144-8-200604180-00009

13. Li C, Yang WH, Zhou J, et al. Risk factors for predicting postoperative complications after open infrarenal abdominal aortic aneurysm repair: results from a single vascular center in China. J Clin Anesth 2013;25:371378. https://doi.org/10.1016/j.jclinane.2013.01.013

14. Miskovic A, Lumb AB. Postoperative pulmonary complications. BJA 2017;118:317-334. https://doi. org/10.1093/bja/aex002

15. Oberg B, Poulsen TD. Obesity: an anaesthetic challenge. Acta Anaesthesiol Scand 1996;40:191-200. https://doi.org/10.1111/j.1399-6576.1996.tb04419.x

16. Dindo D, Muller MK, Weber M, Clavien PA. Obesity in general elective surgery. Lancet 2003;361:2032-2035. https://doi.org/10.1016/S0140-6736(03)13640-9

17. Gronkjaer M, Eliasen M, Skov Ettrup LS, et al. Preoperative smoking status and postoperative complications: a systematic review and Meta-Analysis. Ann Surg 2014;259:52-71. https://doi.org/10.1097/ SLA.0b013e3182911913

18. Qaseem A, Snow V, Fitterman N, et al. Risk assessment for and strategies to reduce perioperative pulmonary complications for patients undergoing noncardiothoracic surgery: a guideline from the American College of Physicians. Ann Intern Med 2006;144:575-580. https://doi.org/10.7326/0003-4819144-8-200604180-00008

19. Hall JC, Tarala RA, Hall JL, Mander J. A multivariate analysis of the risk of pulmonary complications after laparotomy. Chest 1991;99:923-927. https://doi. org/10.1378/chest.99.4.923

20. Hollmann MW, Wieczorek KS, Smart M, Durieux ME. Epidural anesthesia prevents hypercoagulation in patients undergoing major orthopedic surgery. Reg Anesth Pain Med 2001;26:215-222. https://doi. org/10.1053/rapm.2001.23209
21. Pedersen T, Viby Mogensen J, Ringsted C. Anaesthetic practice and postoperative pulmonary complications. Acta Anaesthesiol Scand 1992;36:812-818. https://doi. org/10.1111/j.1399-6576.1992.tb03570.x

22. Kocabas A, Kara K, Ozgur G, Sonmez H, Burgut R. Value of preoperative spirometry to predict postoperative pulmonary complications. Respir Med 1996;90:25-33. https://doi.org/10.1016/s09546111(96)90241-3

23. Zhang Z, Pereira SL, Luo M, Matheson EM. Evaluation of blood biomarkers associated with risk of malnutrition in older adults: a systematic review and meta-analysis. Nutrients 2017;9:829. https://doi.org/10.3390/ nu9080829

24. Karas PL, Goh SL, Dhital K. Is low serum albumin associated with postoperative complications in patients undergoing cardiac surgery? Interact CardioVasc Thorac Surg 2015;21:777-786. https://doi.org/10.1093/ icvts/ivv247

25. Hardt J, Pilz L, Magdeburg J, Kienle P, Post S, Magdeburg R. Preoperative hypoalbuminemia is an independent risk factor for increased high-grade morbidity after elective rectal cancer resection. Int J Colorectal Dis 2017;32:1439-1446. https://doi. org/10.1007/s00384-017-2884-7

26. Li P, Li J, Lai Y, et al. Perioperative changes of serum albumin are a predictor of postoperative pulmonary complications in lung cancer patients: a retrospective cohort study. J Thorac Dis 2018;10:5755-5763. https:// doi.org/10.21037/jtd.2018.09.113

27. Ryan AM, Hearty A, Prichard RS, Cunningham A, Rowley SP, Reynolds JV. Association of hypoalbuminemia on the first postoperative day and complications following esophagectomy. J Gastrointest Surg 2007;11:1355-1360. https://doi.org/10.1007/ s11605-007-0223-y

28. Kim S, McClave SA, Martindale RG, Miller KR, Hurt RT. Hypoalbuminemia and clinical outcomes: what is the mechanism behind the relationship? Am Surg 2017;83:1220-1227.

Ethics approval: Ufuk University NonInterventional Clinical Research approved by the Ethics Committee (date: 06/06/2013 and number: 060620133).

\section{Author contributions}

E.B thesis research articles is manufactured

Study design: E.E.A.

Acguisition of data: E.B., S.A.B.

Analysis and interpretation of data: D.H, E.E.A., E.B.

Dradfting of manuscript: E.B., E.E.A., D.H. 
Critical revision: E.B, E.E.A., D.H.

Statistical analysis: E.B., E.E.A., S.A.B. 